\title{
$\mathrm{CO}_{2}$ 削減のために強アルカリ水中に工作機械を浸漬する技術の開発*
}

\author{
田辺 郁男 ${ }^{* 1}$, ジュニオール ライムンド ダ クルス ${ }^{* 2}$ \\ 坂口 暢也 ${ }^{* 2}$, 金子 義幸 ${ }^{* 3}$
}

\section{Development of Technology Regarding Soaking Machine Tool in Strong Alkaline Water for Reduction of $\mathrm{CO}_{2}$}

\author{
Ikuo TANABE ${ }^{* 1}$, Junior Raimundo Da CRUZ, \\ Nobuya SAKAGUCHI and Yoshiyuki KANEKO \\ ${ }^{* 1}$ Nagaoka University of Technology. Dept. of Mechanical Engineering \\ 1603-1Kamitomioka-machi, Nagaoka, Nigata, 940-2188 Japan
}

In the $21^{\text {st }}$ century, as it is important to produce products with care for protecting the earth, a producer must be careful to conserve energy, save resources and reduce waste which pollutes environment. On the other hand, in case of a machine tool, much lubricating oil was used for smooth drive, electrical energy of forced cooling was used for high accuracy, and much cutting oil was also used for lubrication and cooling. This is large problem for protecting the earth. Therefore the soaking machine tool in strong alkaline water were developed and evaluated. Several elements of a machine tool were firstly investigated for alkali-proof. Then the bench lathe was remodeled and soaked in the vessel with strong alkaline water (pH12.5), thermal deformation between the spindle and the tool post was measured for evaluation of accuracy. And turning using the bench lathe was performed for investigating the effect of water evaporation in the strong alkaline water. It is concluded from the results that; (1) Alkali-proof regarding several elements of a machine tool were cleared in the experiment, (2) Thermal deformation of the bench lathe for bathing was very small in spite of no-forced cooling, (3) Accuracy of the machne tool was very good and the tool life was very long in spite of no-cutting oil, (4) The soaking machine tool in strong alkaline water was economical and eco-friendly.

Key Words : Forced Cooling, Machine Tool, Bathing, High Accuracy, Strong Alkaline Water, Cutting

\section{1. 緒言}

高精度な加工のために多くの熱変形対策が工作機械に施されている(1), (2), (3). また，高精度化と生産性向上のた めに多くの切削発熱強制冷却技術も確立されている(4), (5), (6). これらの対策の多くが，複数台の冷凍機の強制冷却 能力を利用し，発熱量を発熱箇所付近で効率よく除去し，工作機械構造や工具への熱影響を強制的に抑制する手 法である。しかし，現在，地球環境保全に配慮したものづくり(7)がごく一般的に要求されるようになってきてお り，21 世紀型加工技術として，高精度，高生産性，高信頼性に加えて，環境保全に配慮したものづくりが必要と されており，先の工作機械熱変形対策や工具強制冷却対策においても，省エネルギーと環境保全に充分に配慮し た対策が要求され，それらに対してさらなる対策が必要になってきている.

そこで本研究では，鋼に対して耐食性のある強アルカリ水中に工作機械を浸漬した状態にして，その気化熱冷 却効果によって工作機械の熱変形を抑制し，それと同時に浸漬状態になっている加工点付近でも，その気化熱冷 却効果によって切削発熱を強制冷却する加工システムを開発する. 具体的には，卓上旋盤を $\mathrm{pH} 12.5$ の強アルカリ 水槽に浸漬状態にし，その機械構造の熱変形特性，加工精度，工具寿命を実験によって明らかにする．また，こ の技術を確立するために，機械要素の耐強アルカリ特性の解明，強アルカリ水へのマイクロバブルの添加による

\footnotetext{
* 原稿受付 2012 年 6 月 21 日

*1 正員, 長岡技術科学大学（广940-2188 新潟県長岡市上富岡町 1603-1）

*2 長岡技術科学大学

*3 正員, 高松機械工業(株) 技術部

E-mail: tanabe@mech.nagaokaut.ac.jp
} 
冷却能力向上の検討, 本加工システムの環境保全特性の簡単な評価も行う.

\section{2. 工作機械要素部品の耐強アルカリ特性}

水の気化熱による冷却効果は，切削油剤のそれに比べてきわめて大きい(8)にも関わらず，現状において工場内 の工作機械に適用されている例は少ない，それは，水が工作機械，工作物，その周辺の機械要素などの鋼製部品 を腐食させるためである. しかし，腐食工学において平衡状態で金属イオン濃度 (mol/le) の対数值が一6 以下の ときにその金属は腐食されないとみなされており, そのため, 鋼の強アルカリ水に対する腐食特性 ${ }^{(9)}$ に関しては, $\mathrm{pH} 10$ 以上のアルカリ水中では腐食が起こらないことになる. よって pH12.5 を超える強アルカリ水は, 前記の鋼 製部品を腐食することはないと考えられる．また，同様に，鋼以外の工作物材料として，ニッケル基合金のベー スとなるニッケルの場合は, $\mathrm{pH} 8.5 \sim \mathrm{pH} 13.0$ の領域が化学的不動態領域である. さらに, チタン合金のベースと なるチタンの場合は, pH 13.0 以下領域で化学的不動態領域である. これらから, チタン合金やニッケル基合金な ぞの工作物を強アルカリ水中に浸漬状態にして, 水の気化熱によって強制冷却しながら, 工具一の熱影響の軽減 を行う場合, その強アルカリ水の $\mathrm{pH}$ 值は, $\mathrm{pH}$ 10.0 pH 13.0 が適切と考えられる. しかも, 強アルカリ水は界面 浸透性, 剥離分解能力, 乳化・分離能力が大きいため, 洗浄力が極めて大きく, 除菌・腐敗防止作用もあるため, 広域におよぶ洗浄剤として最近よく使用されている．また，強アルカリ水を大気中に放置し続けると， pH は 7.0 に漸近しアルカリ性を失いただの水になるため，環境保全を促進できる洗浄剤として注目されている.

ここでは, 工作物や工具のほか, 工作機械部品や工作機械関連の機械要素の而強アルカリ特性を実験で明らか にする. 表 1 に実験で使用する強アルカリ水を生成する装置の仕様を示す. 小型の生成装置で, 極めて容易に $\mathrm{pH}$ 12.5 の強アルカリ水を生成することができる. 表 2 に示すように, 加工関連材料のアルカリ水中における腐食特 性を実験で確認した。 工作機械構造材料, 工作物, 工具, 工具のコーティング材料, 工作機械要素部品, 工作機 械用電気部品, その他工作機械部品として利用されそうな素材, 塗料の強アルカリ而性を実験で確認するため表 2 に示寸ように, これらの材料 (詳細は表 3 に示寸) を $\mathrm{pH} 12.5$ のアルカリ水の入った容器に入れ, 温度 $20 \pm 1{ }^{\circ} \mathrm{C}$, 湿度 $60 \%$ 一定の恒温室に 2 カ月間放置した. アルカリ水は 1 週間に 1 度入れ替えをして $\mathrm{pH}$ 值を維持した.

而搔アルカリ特性の実験結果を表 3 に示寸. 金属では, アルミニウム, アルミニウム合金, 銅, 銅合金以外は, 強アルカリ水中, および強アルカリ水面付近に 2 カ月間放置しても腐食しなかった. そのため, 多くの工業材料 を強アルカリ水中に浸漬状態にして, 切削加工を行うことが可能であると考える. 近年, 工具のコーティング材 料として, 高硬度と低摩擦係数を特長とする TiAlN や TiAl Cr が使用されているが, 成分に $\mathrm{Al}$ が介在しているた め腐食が促進し, とくに Al 含有量が多くなるとその腐食傾向は顕著に表れた. オイルシールは内部に設置されて いるバネ，排気クリーナは保護用のアルミニウム製金網，その他電気部品の端子台がそれぞれ腐食した．このよ うに, 機械要素部品と電気要素部品では組立や梱包等に使用されているネジ, バネ, 端子台等の部品に, アルミ ニウムや銅を合金材料として含有している場合があり，腐食や変色が起こるので注意が必要である．グリースが 封入されている軸受やリニアガイドに関しては, 油の流失もなく, 強アルカリ水の浸漬前後で駆動特性（軸受は 外輪に巻き付けた糸に荷重つけ回転速度測定, リニアガイドは傾斜板上の転がり速度測定）に変化はなかった. 浸漬したサーボモータは, 2 カ月後に乾燥させた後, NC 旋盤に組込み仕様通りの機能が出ることを確認した. DLC も而強アルカリ特性があり, 工作機械を強アルカリ水中に浸漬させたとき, その摺動面の固体潤滑剤として 使用寸ることが可能である. また, 卓上旋盤（後述）を $\mathrm{pH} 12.5$ のアルカリ水の入った容器に 2 カ月間浸漬させ て継続的に実験を行ったところ, 正常な稼働で，その後の目視観察では腐食・変色がなく，浸漬前と全く同等の 正常な稼働を確認した.

Table 1 Specification of the system for making strong alkaline water

\begin{tabular}{|l|c|}
\hline Method of generation & Closed generation type \\
\hline Value of $\mathrm{pH}$ & $\mathrm{pH} 12.5$ \\
\hline Quantity of generation & $10 \mathrm{l} / \mathrm{h}$ \\
\hline Voltage \& Power & $100 \mathrm{~V} \& 300 \mathrm{~W}$ \\
\hline Size & $495 \mathrm{~W} \times 430 \mathrm{D} \times 1100 \mathrm{H}$ \\
\hline
\end{tabular}

Table 2 Condition of corrosion test

\begin{tabular}{|l|l|}
\hline Medium in the vessel & Strong alkaline water $(\mathrm{pH} 12.5)$ \\
\hline Ambient conditions & Room temp.: $20 \pm 1{ }^{\circ} \mathrm{C}$, Humidity: $60 \%$ \\
\hline Period & Two months \\
\hline
\end{tabular}


Table 3 Results of the proof test for two month in alkaline water with $\mathrm{pH} 12.5$

\begin{tabular}{|c|c|c|c|c|c|c|c|}
\hline \multirow{3}{*}{\begin{tabular}{|l|} 
Machine \\
tool \\
stracture \\
\end{tabular}} & $\mathrm{S} 45 \mathrm{C}$ & $\bigcirc$ & Changeless condition & \multirow{7}{*}{$\begin{array}{l}\text { Machine } \\
\text { element }\end{array}$} & Rubber bushing & $\bigcirc$ & Changeless condition \\
\hline & SUS304 & $\bigcirc$ & Changeless condition & & Exhaust cleaner & $\times$ & Corrode and discoloration \\
\hline & Cast iron & $\bigcirc$ & Changeless condition & & Thinned cylinder & $\triangle$ & Only screw corroded \\
\hline \multirow{7}{*}{$\begin{array}{l}\text { Work } \\
\text { piece }\end{array}$} & $\mathrm{Ti}$ & $\bigcirc$ & Changeless condition & & Air chack & $\bigcirc$ & $\begin{array}{l}\text { Changeless condition } \\
\text { Same function }\end{array}$ \\
\hline & Ti6Al4V & $\bigcirc$ & Changeless condition & & Check valve & $\triangle$ & Only screw corroded \\
\hline & Inconel 718 & $\bigcirc$ & Changeless condition & & Lubricator & $\bigcirc$ & $\begin{array}{l}\text { Changeless condition } \\
\text { Same function }\end{array}$ \\
\hline & $\mathrm{S} 45 \mathrm{C}$ & $\bigcirc$ & Changeless condition & & Regulator & $\triangle$ & Only screw corroded \\
\hline & Copper & $\triangle$ & Only discoloration & \multirow{11}{*}{$\begin{array}{l}\text { Electrical } \\
\text { element }\end{array}$} & $\begin{array}{l}\text { Push-button } \\
\text { switch }\end{array}$ & $\triangle$ & $\begin{array}{l}\text { Terminal corroded } \\
\text { Screw corroded }\end{array}$ \\
\hline & Brass & $\triangle$ & Only discoloration & & Command switch & $\triangle$ & $\begin{array}{l}\text { Terminal corroded } \\
\text { Screw corroded }\end{array}$ \\
\hline & Aluminum & $\times$ & Corrode & & $\begin{array}{l}\text { Optoelectronic } \\
\text { switch amplifier }\end{array}$ & $\triangle$ & $\begin{array}{l}\text { Terminal corroded } \\
\text { Screw corroded }\end{array}$ \\
\hline \multirow{6}{*}{ Tool } & HSS & $\bigcirc$ & Changeless condition & & Servomotor & $\triangle$ & Only screw corroded \\
\hline & Carbide & $\bigcirc$ & Changeless condition & & Box terminal & $\bigcirc$ & Changeless condition \\
\hline & Cermet & $\bigcirc$ & Changeless condition & & $\begin{array}{l}\text { Electromagnetic } \\
\text { contactor }\end{array}$ & $\times$ & Electromagnet corroded \\
\hline & Diamond & $\bigcirc$ & Changeless condition & & Solenoid valve & $\triangle$ & Only discoloration \\
\hline & $\mathrm{CBN}$ & $\bigcirc$ & Changeless condition & & $\begin{array}{l}\text { Solenoid valve } \\
\text { base }\end{array}$ & $\triangle$ & Only discoloration \\
\hline & Ceramic & $\bigcirc$ & Changeless condition & & Flat cable & $\bigcirc$ & Changeless condition \\
\hline \multirow{3}{*}{$\begin{array}{l}\text { Coating } \\
\text { material } \\
\text { of tool }\end{array}$} & DLC & $\bigcirc$ & Changeless condition & & Cable connector & $\bigcirc$ & Changeless condition \\
\hline & Ti AlN & $\times$ & Discoloration & & $\begin{array}{l}\text { Direct acting two } \\
\text { port solenoid } \\
\text { valve }\end{array}$ & $\triangle$ & $\begin{array}{l}\text { Only screw corroded and } \\
\text { discoloration }\end{array}$ \\
\hline & TiAlCr & $x$ & Discoloration & \multirow{12}{*}{$\begin{array}{l}\text { Basic } \\
\text { material }\end{array}$} & Acrylic acid resin & $\bigcirc$ & Changeless condition \\
\hline \multirow{14}{*}{$\begin{array}{l}\text { Machine } \\
\text { element }\end{array}$} & V-belt & $\times$ & Small crack & & Vinyl chloride & $\bigcirc$ & Changeless condition \\
\hline & Drive belt & $\bigcirc$ & $\begin{array}{l}\text { Changeless condition } \\
\text { Same function }\end{array}$ & & Nylon & $\bigcirc$ & Changeless condition \\
\hline & Timing belt & $\bigcirc$ & $\begin{array}{l}\text { Changeless condition } \\
\text { Same function }\end{array}$ & & Polyurethane & $\bigcirc$ & Changeless condition \\
\hline & O-ring & $\bigcirc$ & $\begin{array}{l}\text { Changeless condition } \\
\text { Same function }\end{array}$ & & Polycarbonate & $\bigcirc$ & Changeless condition \\
\hline & Bearing & $\bigcirc$ & Changeless condition & & Nitrile rubber & $\bigcirc$ & Changeless condition \\
\hline & $\begin{array}{l}\text { Linear } \\
\text { guide }\end{array}$ & $\bigcirc$ & $\begin{array}{l}\text { Changeless condition } \\
\text { Same function }\end{array}$ & & $\begin{array}{l}\text { Polyurethane } \\
\text { rubber }\end{array}$ & $\bigcirc$ & Changeless condition \\
\hline & Ball screw & $\bigcirc$ & $\begin{array}{l}\text { Changeless condition } \\
\text { Same function }\end{array}$ & & Fluoro rubber & $\bigcirc$ & Changeless condition \\
\hline & Oil seal & $\triangle$ & Spring corroded & & $\begin{array}{l}\text { Chloroprene } \\
\text { rubber }\end{array}$ & $\bigcirc$ & Changeless condition \\
\hline & Oil pump & $\times$ & $\begin{array}{l}\text { Terminal corroded } \\
\text { No work }\end{array}$ & & $\begin{array}{l}\text { Chlorosulfonated } \\
\text { Polyethylene } \\
\text { rubber, }\end{array}$ & $\bigcirc$ & Changeless condition \\
\hline & Wire hose & $\bigcirc$ & Changeless condition & & $\begin{array}{l}\text { Oilproof vinyl } \\
\text { mixture }\end{array}$ & $\bigcirc$ & Changeless condition \\
\hline & Excel hose & $\bigcirc$ & Changeless condition & & $\begin{array}{l}\text { Urethane } \\
\text { elastomer }\end{array}$ & $\bigcirc$ & Changeless condition \\
\hline & $\begin{array}{l}\text { Cap } \\
\text { connector }\end{array}$ & $\triangle$ & Only screw corroded & \multirow{3}{*}{ Paint } & Lacquer paint & $\bigcirc$ & Changeless condition \\
\hline & Tube fitting & $\bigcirc$ & Changeless condition & & $\begin{array}{l}\text { Urethane resin } \\
\text { paint }\end{array}$ & $\bigcirc$ & Changeless condition \\
\hline & $\begin{array}{l}\text { Oil level } \\
\text { gauge }\end{array}$ & $\bigcirc$ & Changeless condition & & Epoxy resin paint & $\bigcirc$ & Changeless condition \\
\hline
\end{tabular}
$\bigcirc$ : Enable
$\triangle$ : Only discoloration or only screw corroded
$\times$ : Disable 


\section{3. マイクロバブルを添加による強アルカリ水の見かけ上の熱伝達率の向上}

ここでは，マイクロバブルを添加した強アルカリ水中の冷却特性を簡単な実験によって明らかにする．まず， マイクロバブルの基本特性として，水中に放出したマイクロバブルの水中における寿命を測定した． $30 \mathrm{l}$ の水槽 に $8 \mathrm{l} / \mathrm{min}$ のマイクロバブル (マイクロバブルの粒径分布を図 1 に示寸) を 10 分間供給し, 白濁した強アルカ リ水（pH12.5）が透明になるまでの時間を測定した．その際，同様に強アルカリ水に $10 \mathrm{l} / \mathrm{min}$ の気泡（1 2 mm と 3 5 mm）を供給した場合についても測定を行った. その結果, 図 2 に示すとおり, マイクロバブルは強アル カリ水中で 5 分間程度保持されており, 容器内の強アルカリ水にマイクロバブルを供給した後, 各種工作機械に 配管を通して搬送し，加工時の強制冷却に利用寸ることが可能であることが明らかになった．しかし，1 2 mm もしくは 3 5 mm 程度のサイズの気泡になるとその形体は強アルカリ水中で数秒しか保持されず, 1 台の工作機 械において加工点まで数 $\mathrm{mm}$ の気泡入りの強アルカリ水を供給することは困難であると考えられる.

マイクロバブルを供給した強アルカリ水の強制冷却能力を把握するために, 見かけ上の熱伝達率を測定した.

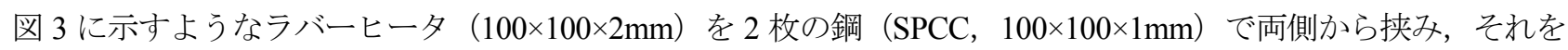
強アルカリ水の入っている容器(L 1190×W 980×H $790 \mathrm{~mm}$ に卓上旋盤を浸漬させたときの水面高さを再現するた めに高さ $430 \mathrm{~mm}$ まで注入)の中央に宙づり状態で配置した. 図 3 には示していないが, 実験は図 6 に示寸卓上旋 盤を設置した状態で，主軸回転による対流の影響が上記センサーの両面に同等に作用するように，主軸と直角

（X-Y 平面）の状態で設置した. ラバーヒータに電源を入れ（50W）, 鋼表面に貼った熱電対の温度が定常状態に なった段階で，鋼表面温度と水槽の平均水温から見かけ上の熱伝達率を測定した．実験は，強アルカリ水の自然



Fig. 1 Bubble size distribution of micro bubble ${ }^{(10)}$

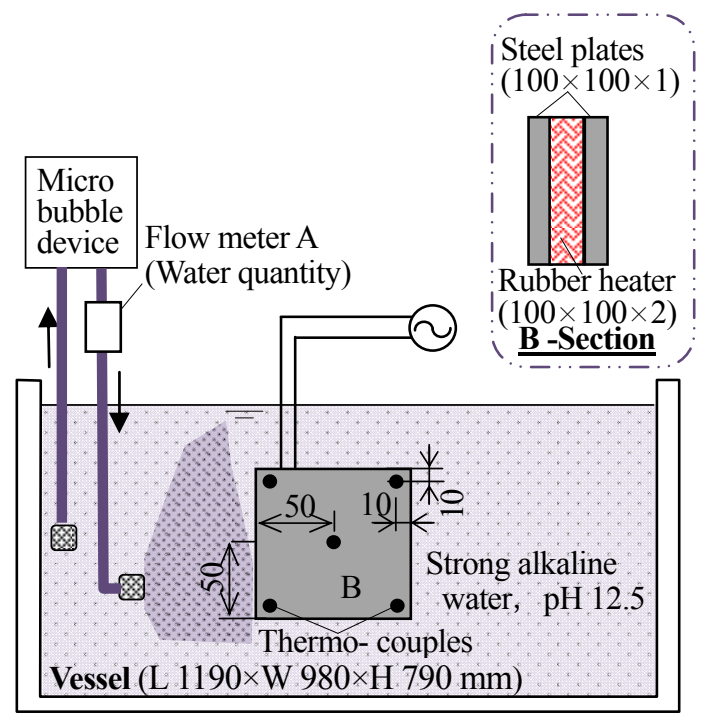

Fig.3 Experimental set-up for measuring heat transfer coefficient of alkaline water with bubbles

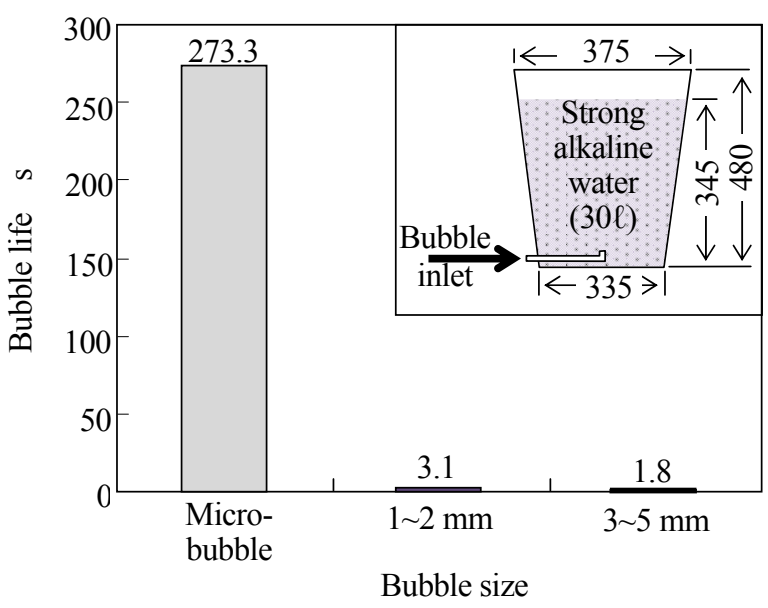

Fig. 2 Relation between bubble size and its life in strong alkaline water

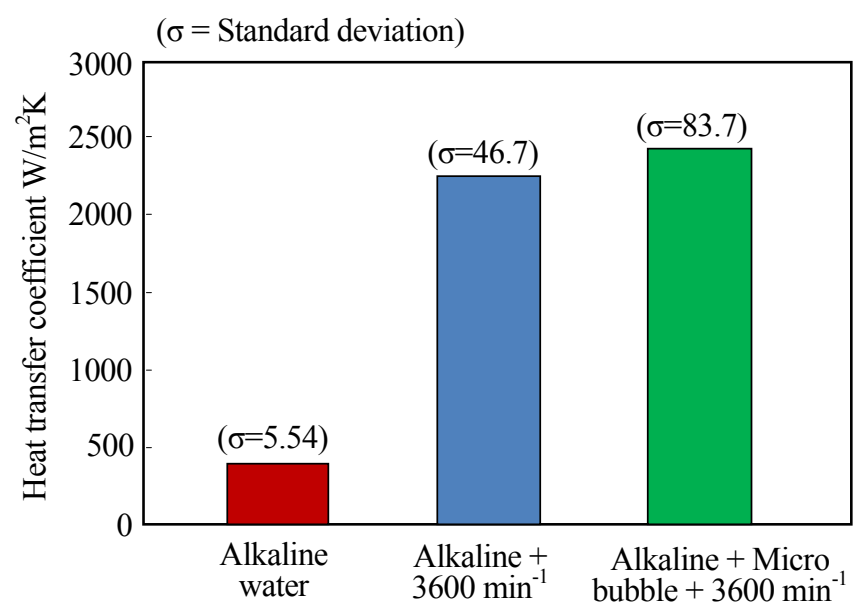

Fig. 4 Relationship between alkaline, micro bubble and $3600 \mathrm{~min}^{-1}$ with the heat transfer coefficient 
対流状態，卓上旋盤の主軸回転 $\left(3600 \mathrm{~min}^{-1}\right)$ の追加，さらに卓上旋盤の主軸回転 $\left(3600 \mathrm{~min}^{-1}\right)$ にマイクロバブ ル供給（8 l/min）の追加をパラメータとした.

図 4 に見かけ上の熱伝達率の測定結果を示す．強アルカリ水の自然対流中に比べ，主軸回転による対流の影響 で 5.5 倍に，さらにマイクロバブルを追加すると 6 倍に熱伝達率が向上した．この結果より，主軸回転による強 制対流の効果が支配的であり, マイクロバブルを添加したときの熱伝達率の改善効果は $8.5 \%$ 程度 $(=2550 / 2350$, 10\%弱) であった。

\section{Soaking 卓上旋盤の熱変形特性と浸漬状態の加工特性}

\section{$4 \cdot 1$ 熱変形特性}

表 4 のような仕様の卓上旋盤（自作）を用い，それを図 5 の写真のようにマイクロバブルを添加した強アルカ

Table 4 Specification of the bench lathe in the experiment

\begin{tabular}{|l|l|c|}
\hline \multirow{3}{*}{$\begin{array}{l}\text { Head } \\
\text { stock }\end{array}$} & Height of center from bed & $177 \mathrm{~mm}$ \\
\cline { 2 - 3 } & Height of center from floor & $337 \mathrm{~mm}$ \\
\cline { 2 - 3 } & Spindle speed & Max. $3600 \mathrm{~min}^{-1}$ \\
\hline \multirow{2}{*}{ Bed } & Size $(\mathrm{W} \times \mathrm{L} \times \mathrm{H})$ & $600 \times 360 \times 660$ \\
\hline Tool post & Stroke of Y axis & $30 \mathrm{~mm}$ \\
\hline Table & Stroke of Z axis & $200 \mathrm{~mm}$ \\
\hline \multirow{2}{*}{ Motor } & Power & $0.75 \mathrm{~kW}$ \\
\cline { 2 - 3 } & Speed control & Inverter \\
\hline Mass & & $200 \mathrm{~kg}$ \\
\hline
\end{tabular}

- Thermocouple

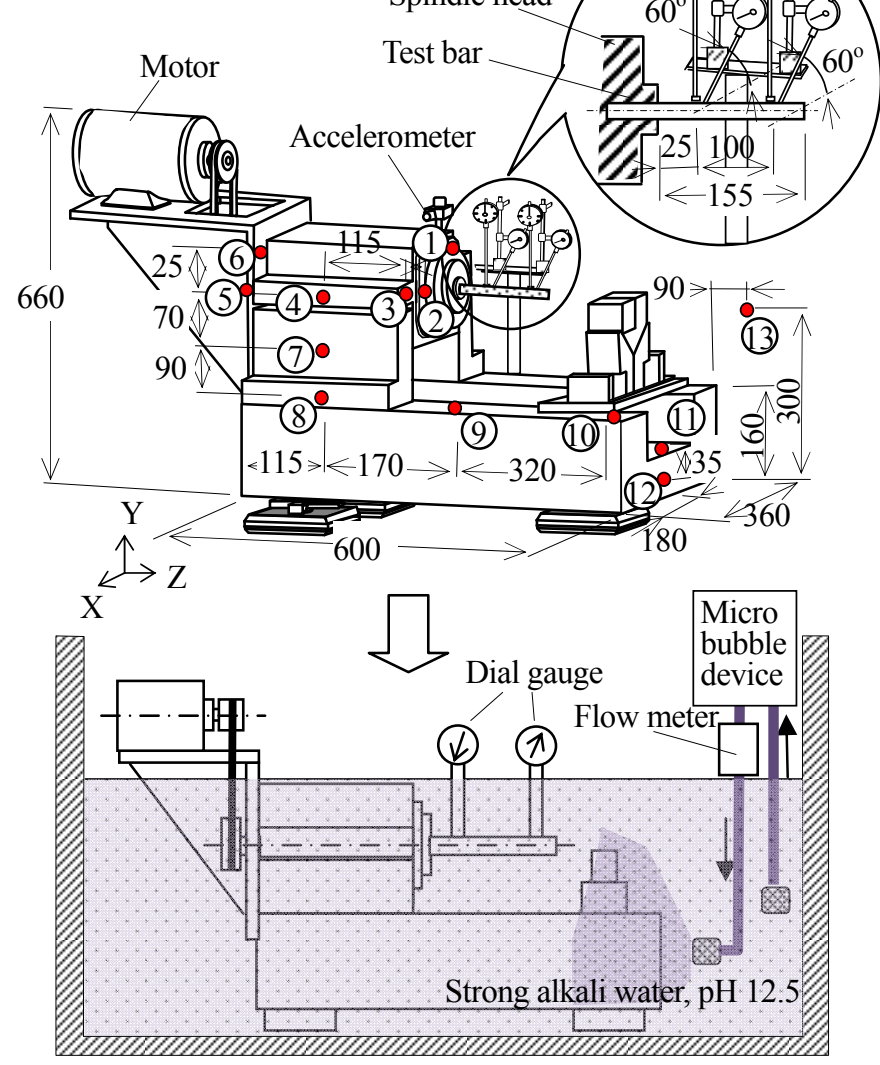

Vessel $($ L $1190 \times$ W $980 \times$ H 790 mm)

Fig. 6 Schematic view of the experiment using the bench lathe in strong alkali water with micro bubble

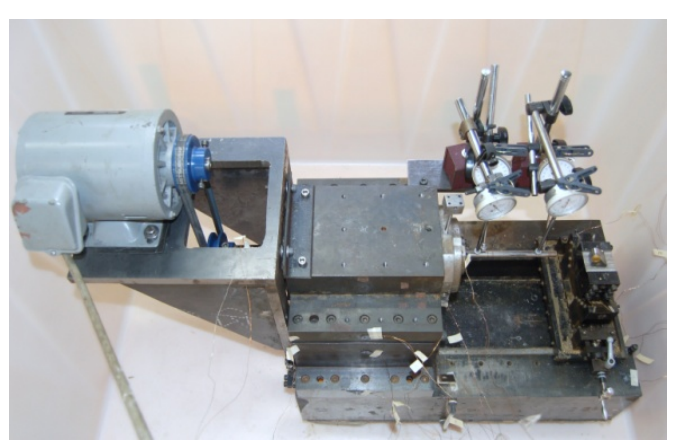

(a) Without strong alkali water



(b) With strong alkali water

Fig. 5 Photograph of the experimental set-up

- Thermocouple

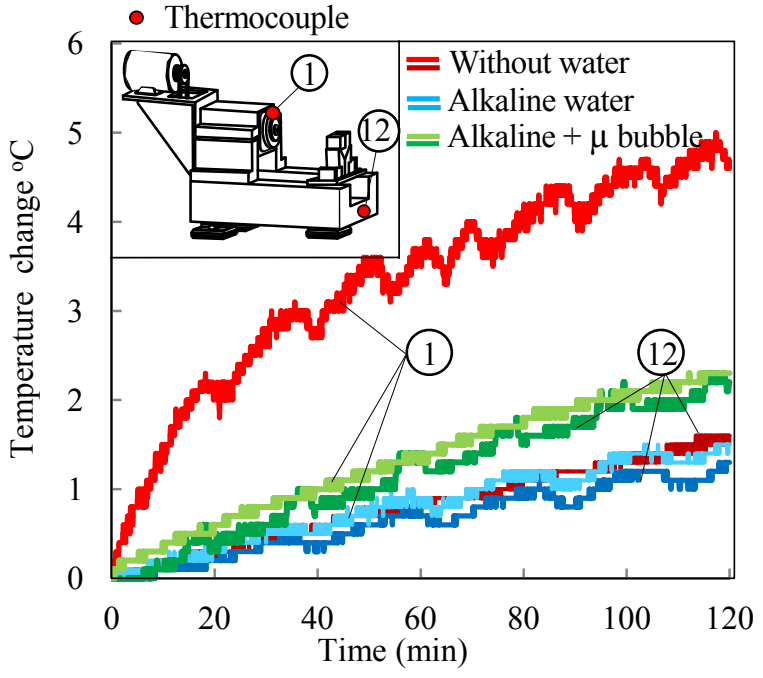

Fig. 7 Temperature change of the bench lathe in strong alkali water with micro bubble operated in $3600 \mathrm{~min}^{-1}$ 


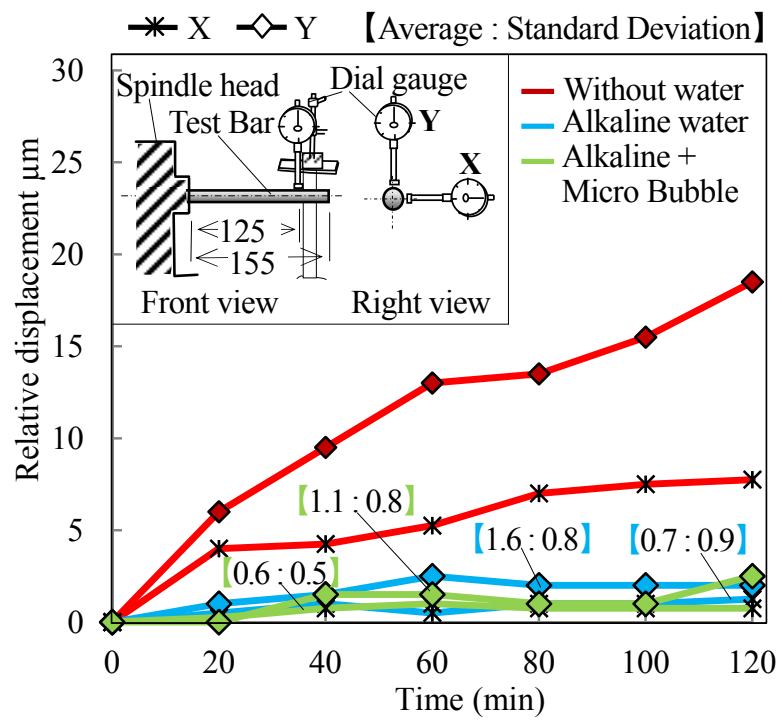

(a) Relative displacement

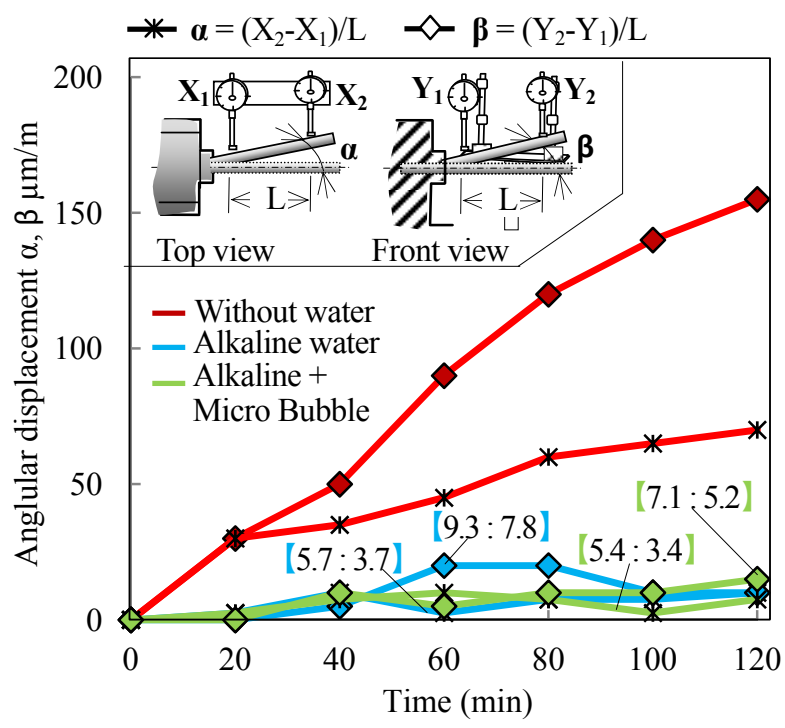

(b) Angular displacement

Fig. 8 Thermal deformation of the bench lathe in strong alkali water with micro bubble

リ水を入れた水槽中にモータ部のみを除いて浸漬状態にして，そのときの熱変形特性を実験で調べた.

図 6 に実験の概略を示す. L 1190×W 980×H 790 mm の容器内に卓上旋盤を搭載し, pH12.5 の強アルカリ水 475 もを入れ， 8 l/minのマイクロバブルを連続的に供給し，アイドリング状態のまま主軸回転数 $3600 \mathrm{~min}^{-1}$ で連続的 に主軸を回転させ，テストバーの X, Y 方向各 2 箇所の熱変形をダイヤルゲージで測定し，図中の印に取付けた $\mathrm{T}$ 型熱電対で機械構造の温度を測定した. 測定は 2 時間行った. また, 比較のために強アルカリ水を注入しない 場合，強アルカリ水を注入しマイクロバブルを供給しない場合についても実験を行った.

図 7 に工作機械（主軸端面(1)とベッドの端(12)）の温度上昇の測定結果を示す．加工精度に大きく影響する工作 機械各部の温度上昇（定常状態の最大值（主軸台端面(1)））が，乾式で $5.0^{\circ} \mathrm{C}$, 主軸回転のみで $1.4^{\circ} \mathrm{C}$, さらにマイ クロバブルを添加した強アルカリ水では $2.2^{\circ} \mathrm{C}$ 以内に抑制されており,この強制冷却効果によって熱変形がきわめ て効果的に抑制できると考えられる．主軸回転のみの場合の温度上昇は主軸軸受の発熱が，また，マイクロバブ

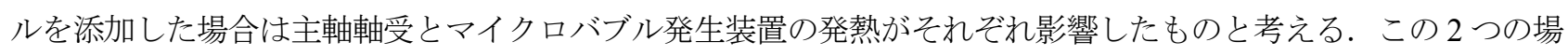
合には機械構造内の温度分布がきわめて小さいと考えられる。

図 8 にテストバー先端の相対変位（X, Y 方向）と相対的傾きの経時変化を示す. 乾式では, 相対変位が $\Delta \mathrm{X}=$ $7.8 \mu \mathrm{m}, \Delta \mathrm{Y}=18.5 \mu \mathrm{m}$, 相対的傾きが $\alpha=70 \mu \mathrm{m} / \mathrm{m}, \beta=155 \mu \mathrm{m} / \mathrm{m}$ に対して, 主軸回転やマイクロバブルを添加し た場合には, 相対変位が $2.5 \mu \mathrm{m}$ 以下，相対的傾きが $20 \mu \mathrm{m} / \mathrm{m}$ 以下と熱変形が抑制されていた. 主軸回転やマイク ロバブルを添加した場合には，図中に 20１20 分の間の各 6データの平均值と標準偏差が示されているが，主軸 回転による対流の効果は大きく $(\Delta \mathrm{X}: 0.7 \mu \mathrm{m}, \Delta \mathrm{Y}: 1.6 \mu \mathrm{m}, \alpha: 5.7 \mu \mathrm{m} / \mathrm{m}, \beta: 9.3 \mu \mathrm{m} / \mathrm{m})$, マイクロバブルの効 果が多少 $(\Delta \mathrm{X}: 0.7 \mu \mathrm{m} \Rightarrow 0.6 \mu \mathrm{m}, \Delta \mathrm{Y}: 1.6 \mu \mathrm{m} \Rightarrow 1.1 \mu \mathrm{m}, \alpha: 5.7 \mu \mathrm{m} / \mathrm{m} \Rightarrow 5.4 \mu \mathrm{m} / \mathrm{m}, \beta: 9.3 \mu \mathrm{m} / \mathrm{m} \Rightarrow 7.1 \mu \mathrm{m} / \mathrm{m})$ 伺える. このように, 卓上旋盤を強アルカリ水槽に浸漬状態にすることによって, 機械構造の熱変形を効果的に抑制でき, 機械の高精度な稼働を安定的に行うことができた。

なお，同様の実験を主軸回転数 $996 \mathrm{~min}^{-1}$ と $3000 \mathrm{~min}^{-1}$ で行ったが, $3600 \mathrm{~min}^{-1}$ の場合と定性的に同様の実験結果 を得た。

\section{$4 \cdot 2$ 浸漬状態の加工特性}

これまで使用した卓上旋盤は $\mathrm{Z}$ 方向の送りが手動のみであるため, 加工後の表面粗さの測定結果に人的誤差が 入る恐れがあるため, ここでは, 図 9 に示すようにマシニングセンタを用い, 加工関連付近のみを水槽で囲い, その中で強アルカリ水中切削を行った。 そのため, 卓上旋盤で強制対流源でもあり発熱源でもあった主軸の浸漬 の影響因子が除外されことになり, これらの影響が, 工具温度, 工具寿命, 工作物表面粗さの測定結果から除外 
されている.ここでは，スロアーチップタイプのバイトを使用して表 5 に示寸切削条件で加工したときの工具寿 命, 加工精度（表面粗さ）を測定し，本手法がどの程度の加工特性に効果を示すかを評価した. 表 5 の加工条件 は S45C 程度の鋼の中仕上げ切削の際によく使用されている加工条件であり, 従来のドライ切削や湿式切削で工 作物 Ti6A14V を切削する場合は，工具にとって熱負荷が大き過ぎて不向きな条件である，パラメータとして，ド ライ切削，一般的な湿式切削，マイクロバブルを添加した強アルカリ水中での切削の 3 種類の実験をした. 工具 寿命試験では逃げ面摩耗量が $0.3 \mathrm{~mm}$ になったときに寿命と判定した。 また，表面粗さは寿命試験開始直後の切 削面と寿命に至った際の切削面の 2 種類について，切削方向に対して直角に測定した.

図 10 にバイト先端温度の最大值の比較を示す. 図 9 に示すように, バイトをバイスに固定し, 工作物を回転さ せて切削を行い, バイト表面に取り付けた熱電対で温度測定を行い, FEM解析によってバイト先端温度を外挿し た. 強アルカリ水中で切削した場合, ドライ切削に比べて $48 \%$ にバイト先端温度が低減していた. さらに, マイ クロバブルを $8 \mathrm{\ell} / \mathrm{min}$ 混入した強アルカリ水中で切削した場合は，ドライ切削に比べて $39 \%$ \%バイト先端温度

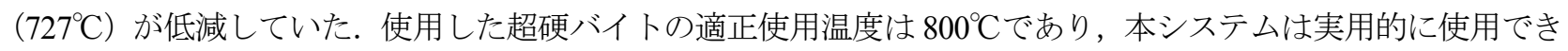
ると考える.

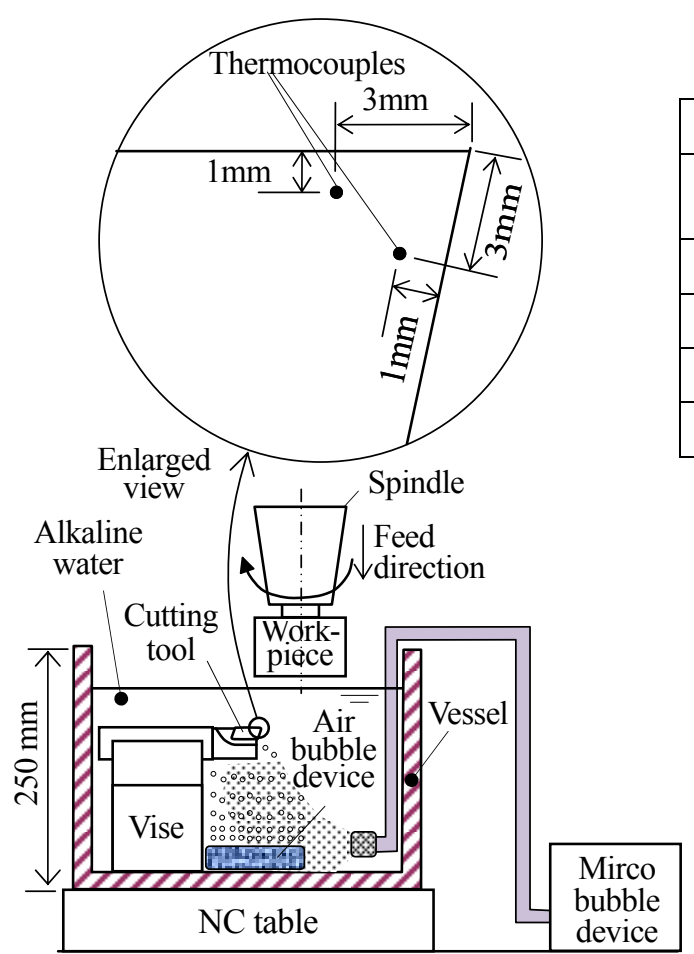

Fig. 9 Experimental set-up for measurement of tool temperature

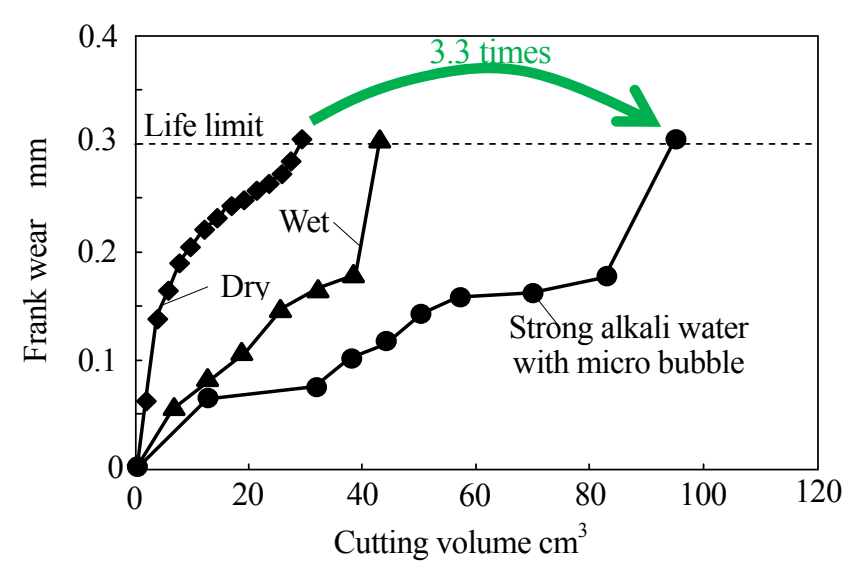

Fig. 11 Results of tool life test
Table 5 Cutting condtions

\begin{tabular}{|c|c|c|}
\hline \multicolumn{3}{|c|}{ Cutting conditions } \\
\hline $\begin{array}{l}\text { Cutting speed } \\
80 \mathrm{~m} / \mathrm{min}\end{array}$ & $\begin{array}{l}\text { Feed speed } \\
0.25 \mathrm{~mm} / \mathrm{rev}\end{array}$ & $\begin{array}{c}\text { Depth of cut } \\
0.4 \mathrm{~mm}\end{array}$ \\
\hline \multicolumn{3}{|c|}{ Work piece } \\
\hline Material : $\mathrm{Ti}$ & \multicolumn{2}{|c|}{ Specific cutting force : $3178 \mathrm{~N} / \mathrm{mm}^{2}$} \\
\hline \multicolumn{3}{|c|}{ Tool } \\
\hline \multicolumn{2}{|c|}{ Rake angle $\cdot 5^{\circ}$} & Coated carbide \\
\hline
\end{tabular}

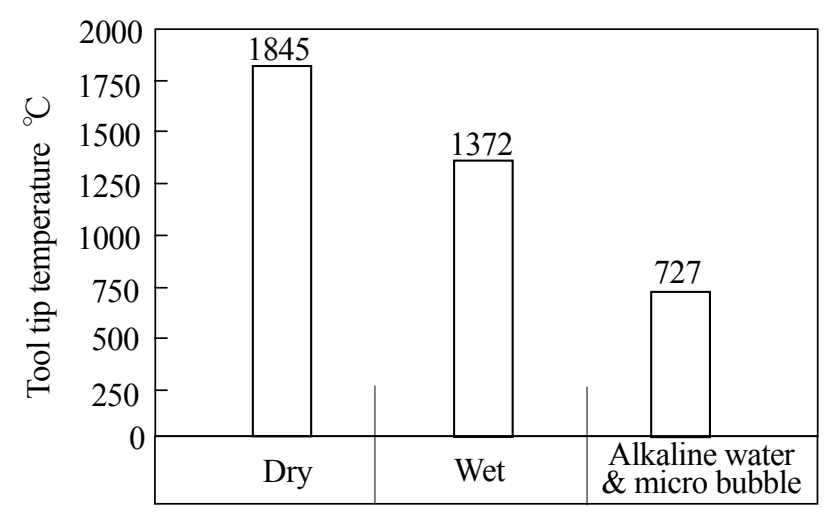

Fig. 10 Experimental results for tool tip temperature



Fig. 12 Results of surface roughness 
図 11 に工具寿命試験結果を示寸. マイクロバブルを加えた強アルカリ水中切削の寿命は, ドライ切削に比べて 工具寿命が 3.3 倍程度伸びている．また，湿式切削に比べて工具寿命が 2 倍程度伸びている．これは，マイクロ バブルを含む強アルカリ水中切削が，難削材切削時に発生する熱を効率よく除去することができたためと考えら れる．これは，本手法の強アルカリ水中切削を使用することによって，S45C 程度の中仕上げ切削条件が Ti6A14V のような難削材の切削に対しても十分に対応可能な加工条件になったことを示しており，本システムは有効であ ったと考えられる. なお, 工具顕微鏡を用いた観察の結果, チップ先端孔付近での割れやクラックの発生は観察 されなかった。

図 12 に表面粗さ（最大高さ）Rzの測定結果を示す. 強アルカリ水中切削した場合は, 表面粗さ $R z$ がドライ切 削や一般的な湿式切削のそれに比べてそれぞれ 70 \% 89 \%となっている. これは, 本システムの冷却効果で工 具温度上昇が抑制されたことにより，工具の熱変形が抑制されたのみではなく，工具の硬度の低下も抑制され工 具剛性も維持されたことにより, 工具先端位置の変動が抑制されたためと考えられる.

\section{5. 環境保全特性と加エコストの簡単な考察}

最後に，排出 $\mathrm{CO}_{2}$ 量を検討することによって本手法の環境負荷に対する簡単な評価を行った。ここでは，基本 的には使用したすべての装置・機器・工作機械の消費電力量を，電力会社が供給するために発電で排出してしま う $\mathrm{CO}_{2}$ 量に換算して比較するが，さらに稼働中に消費した切削油剤の廃油処理によって排出される $\mathrm{CO}_{2}$ 量もそこ に加算して, 従来の湿式切削の場合と本手法を適用した場合の排出 $\mathrm{CO}_{2}$ 量を比較する. 従来の方法では, 稼働時 における工作機械, オイルポンプ, 冷凍機の各消費電力量と, 廃油処理時の排出 $\mathrm{CO}_{2}$ 量から合計排出量を算出し た. また, 本手法の場合はマイクロバブル発生装置, 強アルカリ水生成装置, 切屑除去用ポンプ稼働時の消費電 力量をもとに排出 $\mathrm{CO}_{2}$ 量を算出した.

表 6 に従来の湿式切削の排出 $\mathrm{CO}_{2}$ 量の計算結果を示寸. まず, 従来の方法では, マシニングセンタ $(3.6 \mathrm{~kW})$, オイルポンプ $(1.2 \mathrm{~kW})$, 冷凍機 $(2.2 \mathrm{~kW})$ の合計 $7.0 \mathrm{~kW}$ の電力で, 1 日 8 時間, 1 年 250 日稼働させた場合を想 定した. この場合算出される消費電力量は $14000 \mathrm{kWh} （ 7.0 \mathrm{~kW} \times 8 \mathrm{~h} \times 250$ days $)$ となり, 排出 $\mathrm{CO}_{2}$ 量への換算係数

Table $6 \mathrm{CO}_{2}$ emission of conventional wet cutting

\begin{tabular}{|c|c|c|c|c|c|}
\hline \multicolumn{3}{|c|}{ Machining center, Oil pump \& Cooling unit } & \multicolumn{3}{|c|}{ Waste oil disposal } \\
\hline Power consumption & $\mathrm{kW}$ & 7.0 & Cutting oil amount & $\ell /$ year & 680 \\
\hline Use condition & /year & $\begin{array}{c}8 \mathrm{~h} \times 250 \\
\text { days }\end{array}$ & Refill oil amount & $\ell /$ year & 360 \\
\hline Consumption electric quantity & $\mathrm{kWh}$ & 14000 & & & \\
\hline $\mathrm{CO}_{2}$ emission & $\mathrm{kg}-\mathrm{CO}_{2} /$ year & 6552 & $\mathrm{CO}_{2}$ emission & $\mathrm{kg}-\mathrm{CO}_{2} /$ year & 2946 \\
\hline Total CO2 emission & $\mathrm{kg}-\mathrm{CO}_{2} /$ year & & 949 & & \\
\hline
\end{tabular}

Table $7 \mathrm{CO}_{2}$ emission of cutting in strong alkaline water

\begin{tabular}{|c|c|c|c|c|}
\hline Calculation factors & $\begin{array}{l}\text { Machining } \\
\text { center }\end{array}$ & $\begin{array}{c}\text { Micro bubble } \\
\text { device }\end{array}$ & $\begin{array}{l}\text { Pump for } \\
\text { removing chip }\end{array}$ & $\begin{array}{c}\text { Strong alkaline } \\
\text { water } \\
\text { generating unit }\end{array}$ \\
\hline Power consumption & 3.6 & 0.56 & 0.0132 & 0.75 \\
\hline $\begin{array}{l}\text { Electric quantity for strong alkaline water } \\
1 \ell \\
\end{array}$ & & & & 0.075 \\
\hline Amount of strong alkaline water & - & - & - & 26094 \\
\hline Use condition & $8 \mathrm{~h} \times 250$ days & $8 \mathrm{~h} \times 250$ days & $8 \mathrm{~h} \times 250$ days & $24 \mathrm{~h} \times 365$ days \\
\hline Consumption electric quantity & 7200 & 1120 & 26.4 & 1957 \\
\hline $\mathrm{CO}_{2}$ emission & 3370 & 524 & 12 & 916 \\
\hline Total $\mathrm{CO}_{2}$ emission & \multicolumn{4}{|c|}{4822} \\
\hline
\end{tabular}


を $0.468 \mathrm{~kg}-\mathrm{CO}_{2} / \mathrm{kWh}$ とすると, 推定される排出 $\mathrm{CO}_{2}$ 量 $\mathrm{CL}_{\mathrm{CO} 2} \quad\left(\mathrm{~kg}-\mathrm{CO}_{2}\right)$ は式(1)から求めることができる(11).

$$
C L_{\mathrm{CO} 2}=0.468 \times W_{\mathrm{E}}
$$

ここで， $W_{\mathrm{E}}$ は消費電力量 $(\mathrm{kWh})$ であり，各装置で発生する消費電力量とする．これよりマシニングセンタ，オ イルポンプ，冷凍機の稼働による排出 $\mathrm{CO}_{2}$ 量は $6552 \mathrm{~kg}-\mathrm{CO}_{2}$ となる.

次に, 廃油処理時の排出 $\mathrm{CO}_{2}$ 量を計算した. ここではオイルタンク容量 $340 \ell$ を 1 年間で 2 回交換するとし, また 1 カ月に 1 回 $30 \ell$ を追加するとして $360 \ell$ （30 l×12 month），合計 $1040 \ell$ を処理する場合を想定した. 推定される排出 $\mathrm{CO}_{2}$ 量は式(2)から求めることができる(12),(13).

$$
\mathrm{CO}_{2} \text { 排出量 } \mathrm{kg}-\mathrm{CO}_{2}=\text { 廃油量 } \mathrm{k} \ell \times \text { 発熱量 } \mathrm{GJ} / \mathrm{k} \ell \times \text { 炭素排出量 } \mathrm{t}-\mathrm{C} / \mathrm{TJ} \times(44 \div 12)
$$

ここで発熱量は $40.2 \mathrm{GJ} / \mathrm{k} \ell$ ，炭素排出量は $19.22 \mathrm{t}-\mathrm{C} / \mathrm{TJ}$ である(13),(14). 式(2)を用いて廃油処理時の排出 $\mathrm{CO}_{2}$ 量を 求めると $2946.3 \mathrm{~kg}-\mathrm{CO}_{2}$ となる. 以上より湿式切削による排出 $\mathrm{CO}_{2}$ 量は合計 $9498.3 \mathrm{~kg}-\mathrm{CO}_{2}$ となる.

表 7 に本手法を適用した場合の排出 $\mathrm{CO}_{2}$ 量を示す. まず, 本報の前半で使用した卓上旋盤ではなく, 後半で使 用したマシニングセンタを使用した場合について検討した. 主電力 $3.6 \mathrm{~kW}$ のマシニングセンタを 1 日 8 時間, 1 年のうち 250 日稼働させた場合を想定した。この場合算出される消費電力量は $7200 \mathrm{kWh} （ 3.6 \mathrm{~kW} \times 8 \mathrm{~h} \times 250$ days $)$ となり, 排出 $\mathrm{CO}_{2}$ 量への換算係数 $0.468 \mathrm{~kg}-\mathrm{CO}_{2} / \mathrm{kWh}^{(11)}$ を用いて, 式(1) と同様にして排出 $\mathrm{CO}_{2}$ 量を求めると 3370 $\mathrm{kg}-\mathrm{CO}_{2}$ となる. 同様にしてマイクロバブル発生装置, 切屑除去用ポンプの排出 $\mathrm{CO}_{2}$ 量を求めるとそれぞれ 524 $\mathrm{kg}-\mathrm{CO}_{2}, 12 \mathrm{~kg}-\mathrm{CO}_{2}$ となる. さらに, 強アルカリ水生成装置による排出 $\mathrm{CO}_{2}$ 量を検討寸る. 強アルカリ水の容量 は 26094 lは, マシニングセンタの全容積 27000 l (=W3000 mm $\left.\times \mathrm{D} 3000 \mathrm{~mm} \times \mathrm{H} 3000 \mathrm{~mm} \times 10^{-6}\right)$ から全機械部 品の体積分 $1026 \ell$ （=機械全質量 $8000 \mathrm{~kg} \div$ 鋼の密度 $\left.7800 \mathrm{~kg} / \mathrm{m}^{3} \times 10^{3}\right)$ を引いた值 25974 りを想定し, さらに, 年間の強アルカリ水の補充量 $120 \mathrm{l}(=10 \mathrm{l} /$ 月 $\times 12$ カ月）を加算した值である. 使用したアルカリ水生成装置 は，電力 $0.75 \mathrm{~kW}$ を使用し， 1 時間で 10 lの $\mathrm{pH} 12.5$ の強アルカリ水を生成することができるため， 1 l当たりの 強アルカリ水を生成するための消費電力量は $0.075 \mathrm{kWh} / \mathrm{l}(0.75 \mathrm{~kW} \times 1 \mathrm{~h} \div 10$ l) となる. 使用したマシニング センタを 1 年間 $\mathrm{pH} 12.5$ の強アルカリ水中に浸漬させるために必要な消費電力量は $1957 \mathrm{~kW}$ となり, 式(1) と同様に 排出 $\mathrm{CO}_{2}$ 量を求めると $916 \mathrm{~kg}-\mathrm{CO}_{2}$ となる. よって本手法適用後の排出 $\mathrm{CO}_{2}$ 量は合計 $4822 \mathrm{~kg}-\mathrm{CO}_{2}$ となる.

図 13 に排出 $\mathrm{CO}_{2}$ 量の比較を示寸. 排出 $\mathrm{CO}_{2}$ 量は今回の条件において 1 年間稼働した場合, $4678 \mathrm{~kg}-\mathrm{CO}_{2}$ の削減 効果 (49.2\%削減) が得られることがわかる. これは, 加工中に切削油剂を使用しないため, 廃油処理で生じる $\mathrm{CO}_{2}$ を削減できるためである. このように, 本手法は切削発熱除去のための切削油剤を使用せず，また，加工精

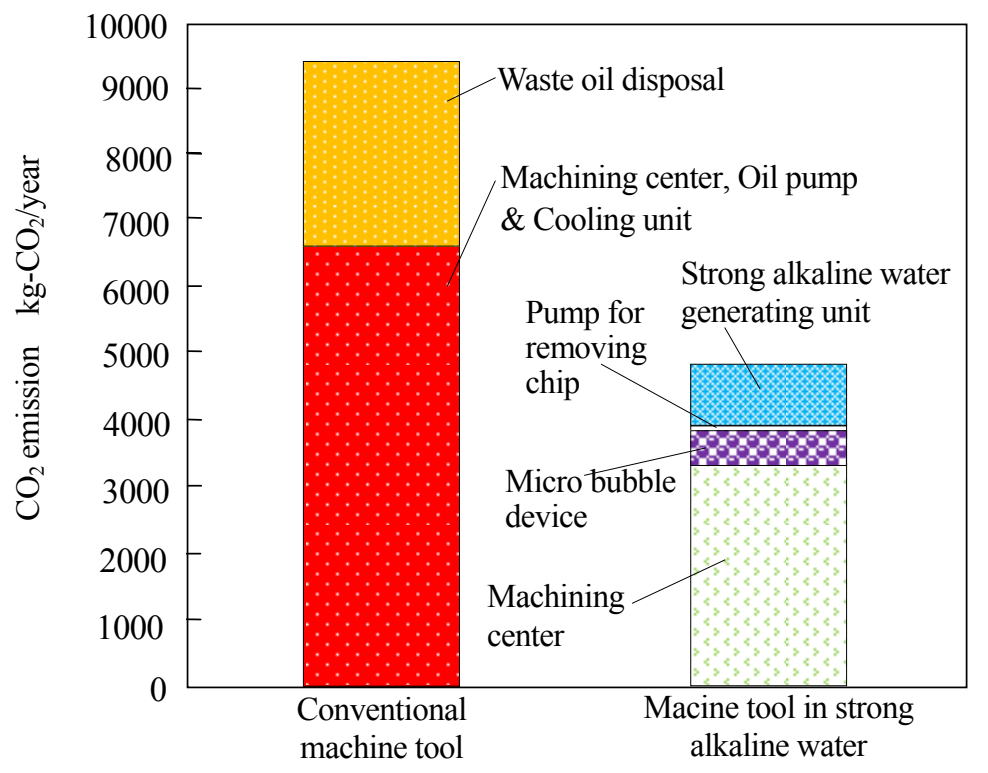

Fig. 13 Comparison of $\mathrm{CO}_{2}$ emission 
度維持のための冷凍機による強制冷却も使用寸ることなく，さらに，加工後の洗浄も不要なため，環境負荷の低 減に有効でありエコロジーであり，工業的にきわめて有効であると考える.

\section{6. 結 言}

本研究の結果をまとめると以下のとおりである.

（1） 強アルカリ水中の熱伝達率が $400 \mathrm{~W} / \mathrm{m}^{2} \mathrm{~K}, 3600 \mathrm{~min}^{-1}$ で主軸回転を加えると熱伝達率が $2350 \mathrm{~W} / \mathrm{m}^{2} \mathrm{~K}$, さらにマイクロバブルを添加すると熱伝達率が $2550 \mathrm{~W} / \mathrm{m}^{2} \mathrm{~K}$ と大きくなり, 冷却効率が向上した.

（2）強アルカリ水中に卓上旋盤を浸漬させることによって, 乾式に比べて温度上昇が $1 / 2$, 相対的変位が $1 / 10 ，$ 相対的傾きが $1 / 12$ にそれぞれ向上した．また，加工領域のみを強アルカリ水中に浸漬させるこ とによって，工具寿命が 3.3 倍，表面粗さが $2 / 3$ にそれぞれ向上した．なお，工具寿命と表面粗さに関 しては，強制対流源・発熱源でもあった主軸台は浸漬されておらず，その影響が除外されている.

（3） マイクロバブルを添加した強アルカリ水中に工作機械を浸漬させることによって，切削油剤や泠凍機 が不要となり，従来の工作機械に比べて年間の $\mathrm{CO}_{2}$ 排出量を半部以下にすることができ，環境保全の 効果があった.

\section{文献}

(1) 田辺郁男, 山中邦彦, 水谷淳之介, 山田泰宏, “熱変形抑制のための新しい旋盤構造設計（三次元零芯設計, セル フ強制冷却，熱同期設計）”，日本機械学会論文集 C 編, Vol. 65, No. 639, (1999), pp.4508-4513.

(2) 田辺郁男, 池田祥生, 浦野好市, “ニューラルネットワークの逆解法による主軸冷却油最適温度の推定（再学習の 効果)，， 日本機械学会論文集 C 編, Vol. 69, No. 679, ( 2003), pp.819-824.

（3）金子義幸，田辺郁男，磯部稔，前田充夫，“環境保全を考慮した熱変形対策による高精度旋盤の開発”，日本機械 学会論文集 C 編, Vol. 70, No. 700, ( 2004), pp.3611-3616.

(4) 田辺郁男, イエー・トット・ソー, 井山徹郎, 阿部洋太朗, “低熱伝導材料加工のためのニューラルネットワーク を用いた工具温度管理”，日本機械学会論文集 C 編, Vol. 77, No. 776, (2011), pp.1556-1564.

（5）田辺郁男，TRUONG HONG Mihn，吉井一夫，“環境にやさしい気化熱冷却を用いた切削加工（第 1 報, 気化熱泠 却の効果と旋盤チップ冷却への適用)”，日本機械学会論文集 C 編, Vol. 66, No. 643, (2000), pp.1026-1030.

（6）田辺郁男，松下幸司，TRUONG HONG Mihn，“セルフ強制冷却を用いた工作機械熱変形の抑制（セルフ強制冷却 モデルの構築と応用）”，日本機械学会論文集 C 編, Vol. 67, No. 660, (2001),pp.2713-2718.

(7) 田辺郁男, 折茂竜哉, “三次元測定機の室温変動に対する熱変形抑制対策（地球環境保全のための省エネルギー対 策) ”，日本機械学会論文集 C 編, Vol. 67, No. 662, (2001), pp.3357-3362.

（8） 田辺郁男，TRUONG HONG Mihn，“環境にやさしい気化熱冷却を用いた切削加工（気化熱冷却モデルの確立と最 適供給水量の計算）”，日本機械学会論文集 C 編, Vol. 67, No. 664, ( 2001), pp.4011-4016.

(9) 下平三郎, “腐食・防食の材料科学”, アグネ技術センター, (1995), pp.30-32, 255-257, 287-288.

(10) 高濃度マイクロバブル発生装置 A-01 型仕椂書, 株式会社資源開発研究所, “マイクロナノバブル発生能力”, http://www.idea-techno.com/pd/micro-bubble/naturan/naturan.html（参照日 2012 年 1 月 28 日).

(11) 環境省, “平成 21 年度の電気事業者ごとの実排出係数, 調整後排出係数等の公表について”, 報道発表資料, (2010), http://www.env.go.jp/press/press.php?serial =13319（参照日 2012 年 3 月 3 日）.

(12) 環境省, “地球温暖化対策の推進に関する法律施行令”, (1999), 第6条第1項第1号, http://law.e-gov.go.jp/htmldata/H11/H11SE143.html(参照日2012年3月3日).

(13) 環境省, “特定排出者の事業活動に伴う温室効果ガスの排出量の算定に関する省令”, (2006), 第2条，別表第5, http:/law.e-gov.go.jp/htmldata/H18/H18F15002002003.html (参照日2012年3 月3 日).

（14）環境省,”温室効果ガス排出量算定に関する検討結果”，表4 (2006), http:// www.env.go.jp/earth/ondanka/santeiho/ kento/h1808/11energy.pdf(参照日2012 年3 月3 日) . 